
\title{
Induced by Antituberculosis Therapy: A Case Report
}

\author{
Tüberküloz Tedavisi Sırasında Gelişen Jeneralize Keratozis Likenozis \\ Kronika Olgusu
}

Illkin Zindanci', Hacer Kuzu Okur², Ebru Zemheri³ , Burce Can', Zafer Turkoglu', Mukaddes Kavala', Özge Akbulak', Filiz Topaloglu'

\begin{abstract}
Keratosis lichenoides chronica $(\mathrm{KLC})$ is a rare and chronic skin disease characterized by erythema, keratotic and lichenoid papules are distributed symmetrically. The histological examination of KLC reveals lichenoid dermatitis with hyper and parakeratosis. Although the etiology and pathogenesis of KLC are unknown, it is suggested that KLC is a variant of lichen planus or lichenoid drug eruptions. We present a case of generalized KLC that occurred during antituberculosis therapy including isoniazid, rifampicin, ethambutol, and pyrazinamide and dramatically improved after cessation of therapy. We report this generalized KLC case in order to draw attention to the side effects that can be seen during tuberculosis treatment.
\end{abstract}

Key words: Tuberculosis treatment, pyrazinamide, keratosis lichenoides chronica, Nekam's disease.

\section{Özet}

Keratozis Likenozis Kronika (KLK), simetrik dağılım gösteren, eritemli, likenoid, keratotik papüllerle karakterize, nadir görülen kronik bir dermatozdur. Histopatolojik incelemede hiperkeratoz ve parakeratozun eşlik ettiği likenoid dermatit bulgusu görülür. Ełyolojisi tam olarak bilinmemekle birlikte liken planus veya likenoid ilaç reaksiyonlarının bir varyantı olduğu düşünülür. Tedavinin kesilmesiyle dramatik bir düzelme gösteren, isoniyazid, rifampisin, etambutol ve pirazinamidli antitüberküloz tedavi sırasında oluşan Jeneralize KLK olgusunu, tüberküloz tedavisi sırasında görülebilecek yan etkilere dikkat çekmek amacıyla sunuyoruz.

Anahtar Sözcükler: Tüberküloz tedavisi, pirazinamid, keratozis likenozis kronika, Nekam's hastalığı.

\footnotetext{
'Department of Dermatology, Medeniyet University, Göztepe Training and Research Hospital, İstanbul, Turkey

${ }^{2}$ Clinic of Chest Diseases, Fatih Sultan Mehmet Training and Research Hospital, İstanbul, Turkey

${ }^{3}$ Department of Pathology, Medeniyet University, Göztepe Training and Research Hospital, İstanbul, Turkey
}

\author{
${ }^{1}$ Medeniyet Üniversitesi, Göztepe Eğitim Hastanesi, Dermato- \\ loji Anabilim Dalı, İstanbul \\ ${ }^{2}$ Fatih Sultan Mehmet Eğitim ve Araştırma Hastanesi, Göğüs \\ Hastalıkları Kliniği, İstanbul \\ ${ }^{3}$ Medeniyet Üniversitesi, Göztepe Eğitim Hastanesi, Patoloji \\ Anabilim Dalı, İstanbul
}

Submitted (Başvuru tarihi): 05.1 1.2013 Accepted (Kabul tarihi): 18.12.2013

Correspondence (iletişim): Hacer Kuzu Okur, Department of Chest Diseases, Fatih Sultan Mehmet Training and Research Hospital, İstanbul, Turkey e-mail: hacerkuzu@hotmail.com 
Keratosis Lichenoides Chronica (KLC), or Nekam's disease, is a rare chronic mucocutaneous dermatitis characterized by keratinization. It most commonly occurs in adolescents and young adults, with a slight predominance in males (M/F: 1.35:1) $(1,2)$. Although its etiology is unknown, systemic diseases, infections, and drugs have been reported as possible trigger factors (3). We report a case of KLC that developed secondary to antituberculosis treatment while on treatment for pulmonary tuberculosis.

\section{CASE}

A 58-year-old male patient was admitted to our clinic with the complaint of a generalized rash with erythematous, scaly plaques. He was diagnosed with tuberculosis two months prior and isoniazid, rifampicin, ethambutol, and pyrazinamide treatment was initiated. However, on the tenth day of the treatment, he developed a rash starting from the torso disseminating throughout the body. In the dermatological examination, violaceous-erythematous, scaly, infiltrated plaques were found all over the body. Lesions were mostly located on the torso, and upper and lower extremities and showed a tendency for coalescence (Figure 1-3). Laboratory tests including blood biochemistry, complete blood count, anti-HIV, and hepatitis markers were all normal. A biopsy taken from the lesions revealed focal parakeratosis, irregular acanthosis, focal exocytosis, colloid bodies, basal vacuolar degeneration, necrotic cells, and lichenoid infiltration (Figure 4). The patient was diagnosed with KLC. The patient's antituberculosis treatment was terminated and a topical methylprednisolone aceponate and oral cetirizine treatments were initiated. All lesions have improved on the 15th day of the treatment. Therefore, we suspected that antituberculosis treatment triggered the current condition. However, since the antituberculosis treatment was mandatory, after consulting a pulmonologist, we decided to administer antituberculosis drugs intermittently, in a consecutively at precise intervals in order to determine the responsible drug. Accordingly, every week the patient was reintroduced his medications successively (isoniazid 300 $\mathrm{mg} /$ day, ethambutol $1500 \mathrm{mg} /$ day, and rifampicin 600 $\mathrm{mg} /$ day, respectively), under the control of the pulmonary medicine unit, and the patient did not experience any side effects during that time. The last drug added to the intermittent treatment protocol was pyrazinamide 1500 $\mathrm{mg} /$ day and the patient's erythematous, scaly lesions relapsed on his torso on the third day of pyrazinamide treatment. Thinking that pyrazinamide was the triggering drug, it was excluded from the treatment protocol, thus, the patient continued to receive the three-drug protocol. With this treatment protocol, no relapses were observed during nine months of follow-up. The patch test, which was performed after the treatment by using antituberculosis drugs, was positive for pyrazinamide but negative for other anti-tuberculosis drugs.

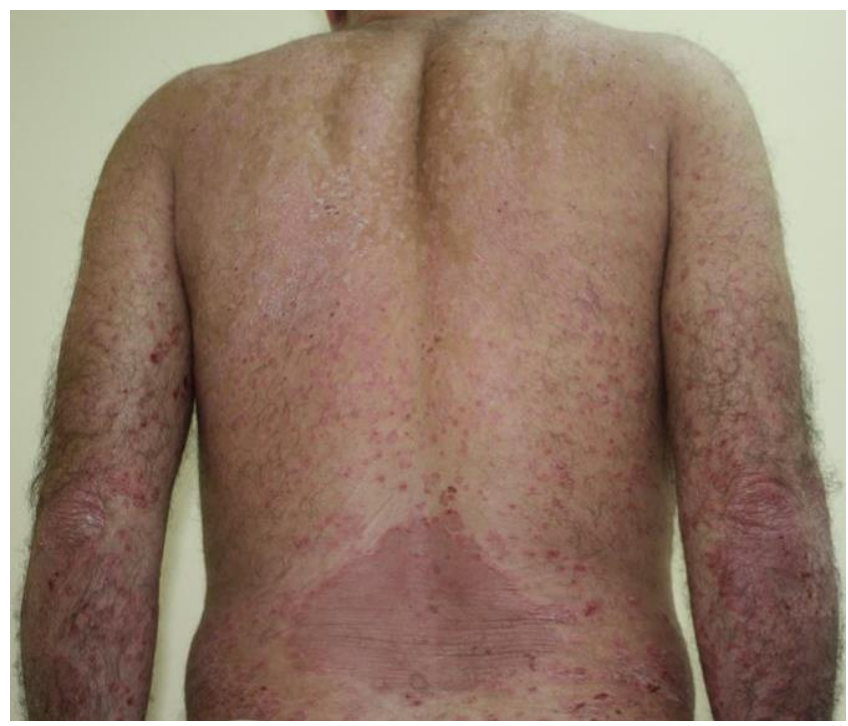

Figure 1: Psoriasis like violaceous-erythematous, scaly, infiltrated plaques

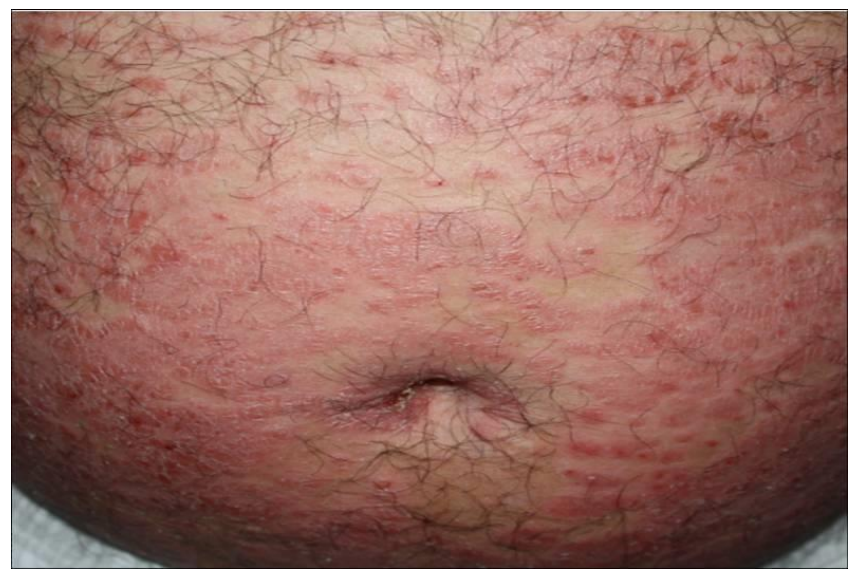

Figure 2: Violaceous-erythematous, scaly, infiltrated plaques on the patient's abdomen

\section{DISCUSSION}

Kaposi first described this entity in 1895 as lichen ruber acuminatus verrucosus et reticularis. The most current and widely accepted term is keratosis lichenoides chroni$\mathrm{ca}(\mathrm{KLC})$, as proposed by Margolis et al. (4) in 1972. It is, as in the current case, characterized by widespread symmetrical lichenoid hyperkeratotic papules that are typically arranged in a linear or reticulate pattern, and erythematous psoriasis-like, scaly plaques $(1,2)$. In $75 \%$ of cases, rash-like or rosacea-like facial seborrheic dermatitis is present, which facilitates diagnosis. Nail dystrophy may be seen in $30 \%$ of these patients and palmoplantar 
keratoderma in approximately $40 \%$ of cases. This skin problem can also be associated with oral manifestations in $50 \%$ of cases presenting as recurrent aphthous ulcers and lesions (4). The current case has presented with erythematous, scaly plaques, which were very clinically similar to psoriasis and there was no accompanying nail or soft tissue involvement.

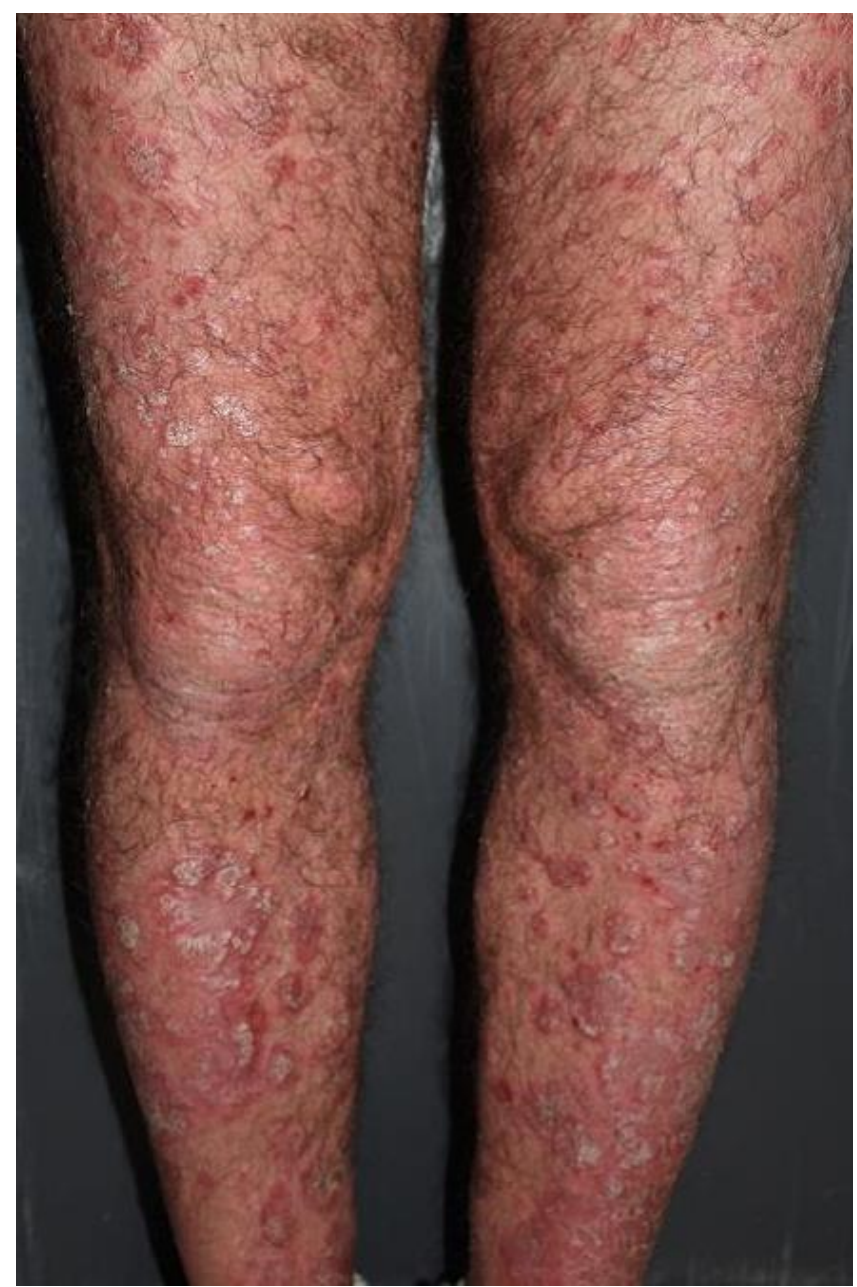

Figure 3: Psoriasis-like lesions on the lower extremities

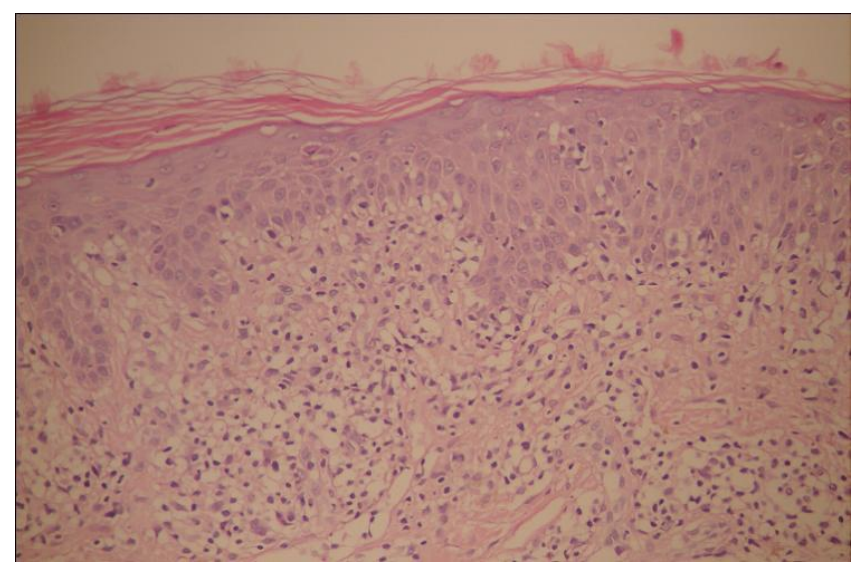

Figure 4: Focal parakeratosis, irregular acanthosis, focally exocytosis, colloid body, and necrotic cell (HEx20)
In the histopathological examination of KLC, the presence of lichenoid dermatitis associated with numerous necrotic keratinocytes, focal parakeratosis, and remnant neutrophils are characteristic. There may be vacuolar alteration of the basal layer along the dermo-epidermal junction $(2,5)$.

Although KLC has some common clinical and dermatopathological features with lichen planus, it is considered to be a distinct entity (6). The etiopathogenesis of $\mathrm{KLC}$ is still unknown but its close similarity to lichenoid drug eruption induced by tuberculostatic and anti-malarial drugs suggest that KLC is a variant of lichenoid druginduced eruptions (3). It has been reported in association with systemic diseases (renal disease, diabetes mellitus, lymphoma, multiple sclerosis, mycosis fungoides, hypothyroidism, and chronic hepatitis), following trauma, and chronic infectious diseases such as toxoplasmosis, and tuberculosis (7). Our patient had no systemic pathology other than pulmonary tuberculosis. The researchers suspected that the KLC lesions developed secondary to the drugs because the eruptions first appeared on the tenth day of the antituberculosis treatment and regressed after the discontinuation of the treatment; however, the responsible drug could not be identified. Since the patient required treatment for pulmonary tuberculosis, antituberculosis drugs were administered to the patient consecutively at precise intervals. Scaly-lichenoid papules similar to the first reaction developed following pyrazinamide, the last drug added to the treatment. Subsequently, pyrazinamide was excluded from the treatment protocol and the treatment continued as three-drug regimen for nine months. During this period, no new lesions developed. Accordingly, the researchers determined that the triggering agent was pyrazinamide. The treatment of $\mathrm{KLC}$ is difficult because the disease is resistant to many different therapies, including topical or systemic corticosteroids, methotrexate, cyclosporine, antibiotics, antimalarials, and sulfones. In some cases, partial responses have been reported with the use of PUVA, narrowband UV-B, and systemic retinoids (8). In the current case, generalized eruptions which were presumed to be induced by pyrazinamide, resolved after the administration of symptomatic treatment and the abandonment of the suspected drug without any further treatment.

As a result, the researchers suggest that KLC should be considered in the differential diagnosis of dermatosis presenting with erythematous, scaly lichenoid papules, and drug intake as the triggering agent must be questioned while recording the history. 


\section{CONFLICTS OF INTEREST}

None declared.

\section{AUTHOR CONTRIBUTIONS}

Concept - I.Z., H.K.O., E.Z., B.C., Z.T., M.K., Ö.A., F.T.; Planning and Design - I.Z., H.K.O., E.Z., B.C., Z.T., M.K., Ö.A., F.T.; Supervision - I.Z., H.K.O., E.Z., B.C., Z.T., M.K., Ö.A., F.T.; Funding - I.Z., E.Z., M.K.; Materials E.Z., I.Z., B.C., Z.T.; Data Collection and/or Processing I.Z., Ö.A.; Analysis and/or Interpretation - I.Z., H.K.O., M.K., E.Z.; Literature Review - I.Z., H.K.O.; Writing - I.Z., Ö.A.; Critical Review - I.Z., M.K., F.T.

\section{YAZAR KATKILARI}

Fikir - I.Z., H.K.O., E.Z., B.C., Z.T., M.K., Ö.A., F.T.; Tasarım ve Dizayn - I.Z., H.K.O., E.Z., B.C., Z.T., M.K., Ö.A., F.T.; Denetleme - I.Z., H.K.O., E.Z., B.C., Z.T., M.K., Ö.A., F.T.; Kaynaklar - I.Z., E.Z., M.K.; Malzemeler - E.Z., I.Z., B.C., Z.T.; Veri Toplama ve/veya İşleme - I.Z., Ö.A.; Analiz ve/veya Yorum - I.Z., H.K.O., M.K., E.Z.; Literatür Taraması - İ.Z., H.K.O.; Yazıyı Yazan - I.Z., Ö.A.; Eleştirel İnceleme - I.Z., M.K., F.T.

\section{REFERENCES}

1. Wozniacka A, Schwartz RA, Omulecki A, Lesiak A, SysaJedrzejowska A. Keratosis lichenoides chronica: a diagnostic and therapeutic challenge. Clin Exp Dermatol 2006; $31: 48-50$. [CrossRef]

2. Çayırlı M, Turan Y, Koç E. Bir keratozis likenoides kronika olgusu. Dermatoz 2012; 3:55-6.

3. Piñol-Aguadé J, De Asprer J, Ferrando J. Lichenoid trikeratosis (Kaposi-Bureau-Barrière-Grupper). Dermatologica $1974 ; 148: 179-88$.

4. Martins LC, Horne M, Moreira Júnior DN, Follador I, Almeida VR. Keratosis lichenoides chronica-case report. An Bras Dermatol 2011 ; 86(4Supl1):S148-51.

5. Böer A. Keratosis lichenoides chronica: proposal of a concept. Am J Dermatopathol 2006; 28:260-75.

6. Konstantinov KN, Sondergaard J, Izuno G, Obreshkova E. Keratosis lichenoides chronica. J Am Acad Dermatol 1998; 38:306-9. [CrossRef]

7. Miller TD, Chilukuri S, Bayer-Garner IB, Hsu S. Keratosis lichenoides chronica. Int J Dermatol 2004; 43:947-50. [CrossRef]

8. Koseoglu RD, Sezer E, Yuksek J. Keratosis lichenoides chronica treated with acitretin plus narrowband ultraviolet B phototherapy. J Dermatol 2008; 35:172-4. [CrossRef] 